\title{
Storage Stability of Guava Leather in Two Type of Packaging
}

\author{
L. Jeebit Singh ${ }^{1 *}$, R.B. Tiwari ${ }^{2}$ and K. Ranjtiha ${ }^{2}$ \\ ${ }^{1}$ Directorate of Horticulture and Soil Conservation, Imphal, Manipur, India \\ ${ }^{2}$ Division of Post Harvest Technology \& Agricultural Engineering, ICAR-IIHR, Bengaluru, \\ Karnataka, India \\ *Corresponding author
}

Key w or d s
$\begin{aligned} & \text { Leather, TSS, } \\ & \text { Biaxially oriented } \\ & \text { polypropylene, } \\ & \text { Punnet, Guava, } \\ & \text { Storage }\end{aligned}$
Article Info
$\begin{aligned} & \text { Accepted: } \\ & \text { 20 June } 2019 \\ & \text { Available Online: } \\ & \text { 10 July } 2019\end{aligned}$

A B S T R A C T

Guava ('Allahabad Safeda') leather was prepared as per FSSAI specification and the effect of packing in punnet and biaxially oriented polypropylene was carried out to study the effect of storage under ambient condition $\left(25 \pm 5^{\circ} \mathrm{C}\right)$. The storage stability, nutritional and microbial quality and sensory changes were evaluated periodically upto 4 months. The leather stored in biaxially oriented polypropylene recorded higher nutrient retention compared to packaging in punnets. There was reduction in moisture, ascorbic acid, non-reducing sugar, total sugar and water activity irrespective of packaging material during storage while acidity, reducing sugar and non-enzymatic browning showed significant increase during the storage. Microbial analysis showed the leathers were safe for consumption till 4 months of storage in both packaging. Sensory acceptability were higher in the samples stored in biaxially oriented polypropylene and remains acceptable upto 4 months of storage.

\section{Introduction}

Guava (Psidium guajava L.) belongs to family Myrtaceae and is a native of tropical America. It is one of the important commercial fruit of tropical as well as subtropical regions. It emits a sweet aroma and is pleasantly sweet and refreshingly acidic in flavour. It ranks third in ascorbic acid content (260 mg/100 g pulp) after barbados cherry $(1500 \mathrm{mg} / 100 \mathrm{~g})$ and aonla $(700 \mathrm{mg} / 100 \mathrm{~g})$.It is an excellent source of pectin and is rich in minerals like phosphorous (23-37 mg/100g), calcium (14-30 $\mathrm{mg} / 100 \mathrm{~g})$, iron $(0.6-1.4 \mathrm{mg} / 100 \mathrm{~g}$ ) as well as vitamins like niacin, pantothenic acid, thiamine, riboflavin, vitamin A (Bose et al., 1999). It has a great demand as a table fruit and also in processing industries (Archana and Siddiqui, 2004) ${ }^{[2]}$. It is common experience that $20-25 \%$ of the fruit is completely damaged and spoiled before it reaches the consumer (Yadav, 1997). So, the best alternative to get better returns from rainy season crops and glut period is through value 
addition. Therefore, to utilize the produce at the time of glut and to save it from spoilage, fresh fruit may be processed into various value added products such as juice, nectar, pulp, leather, jam, jelly, squash, fruit bar or dehydrated products, baby foods, puree, beverage base, syrup, ice-cream and toffee (Leite et al., 2006; Kanwal et al., 2016).

The consumer trend now-a-days is to look for more natural snack foods. Confectionary like sweets and candies made from high amount of sugar has very little nutrition and could cause cavities among children. Fruit leather which is made from fruit can be an alternative confectionary not only to children but also to adults. Being made from natural fruits, fruit leather has all the goodness and nutrients of fruits in it. Fruit bar or leather or slab is a confectionary, self-stable dehydrated product with soft gel like texture. Fruit leathers are made by drying a very thin layer of fruit puree and other ingredients to produce a leathery sheet of dried fruit with a texture similar to soft leather (Andress and Harrison, 1999) ${ }^{[6]}$. Among various processing method, dehydration of fruit pulp to make fruit leather or fruit bar is one of the method which is highly acceptable with long shelf life without refrigeration. Due to concentration during dehydration, the nutritional content of the fruit is highly increased. Fruit leathers also add value to fruit which may otherwise not acceptable for the fresh produce market helping in reducing the postharvest losses. Hence, an experiment to standardise nutritionally rich and tasty guava fruit leather with its storage stability in two types of packaging material i.e. punnets and biaxially oriented polypropylene (BOPP) were conducted.

\section{Materials and Methods}

The present investigation was carried out at Division of Post-Harvest Technology and
Agricultural Engineering, ICAR-IIHR, Bangalore. Guava var. 'Allahabad Safeda' was procured from the IIHR farms. Fully ripe fresh fruits uniform in size and shape, free from transportation injuries, bruises, insect damage and diseases which are uniformly ripened were selected. Fruits were peeled by lye peeling technique (using $0.5 \% \mathrm{NaOH}$ boiling solution for $2 \mathrm{~min}$.) then repeatedly washed using tap water. Peeled fruits were cut into small pieces and pulped using a mixer. Pulp was then passed through a fine sieve to obtain a fine pulp separately. To prevent browning, ascorbic acid (100 mg/ $100 \mathrm{~g}$ ) was added to guava pulp. Pulp TSS was adjusted to $20^{\circ} \mathrm{B}$ using sugar and citric acid at $0.3 \%$ and KMS (potassium metabisulphite) at $600 \mathrm{ppm}$ were added. Pulp of $1 \mathrm{~kg}$ was spread on stainless steel drier trays in the form of a sheet at the rate of $250 \mathrm{~g} / \mathrm{sq}$. ft. The trays were then kept for drying in a cabinet drier at 55 to $60^{\circ} \mathrm{C}$ till a moisture content of $15 \%$ (approx.). The dried sheets of fruit leather were weighted and cut into rectangular slabs of dimension $3.5 \times 7.5 \mathrm{~cm}$ and kept for equalization in airtight plastic boxes overnight.

The prepared guava leather was packed in punnet and BOPP (water vapor transmission rate of $4 \times 10^{-3} \mathrm{~kg} / \mathrm{m}^{2} / \mathrm{d}$ at $90 \% \mathrm{RH}, 38^{\circ} \mathrm{C}$ and an OTR of $2.5 \mathrm{~L} / \mathrm{m}^{2} / \mathrm{d}$ atmosphere at $25^{\circ} \mathrm{C}$ ) then labeled properly for storage at ambient temperature of 22 to $26^{\circ} \mathrm{C}$ with $\mathrm{RH} 70$ to $77 \%$ for a period of four months. Data regarding the yield of fruit bars were recorded. Physicochemical analyses were carried out at initial, two months and four month of storage under ambient conditions $\left(25\right.$ to $\left.35^{\circ} \mathrm{C}\right)$. Fresh pulps and dehydrated leathers were analyzed for various physical and biochemical constituents as per methods described by A.O.A.C. $(2001)^{[7]}$. Total soluble solids were recorded using hand refractrometer (Erma, Japan), nonenzymatic browning (OD at $440 \mathrm{~nm}$ ) by UV visible spectrophotometer (Model T70, PG Instrument) and water activity by water 
activity meter (Rotronic, Hygro Lab). Microbial analysis of leather were carried for total colony forming units, yeast, mould, lactic acid bacteria and coliform bacteria out at the end of storage (4 months) by pour-plate method by incubating at $28 \pm 2^{0} \mathrm{C}$ for 24 to 48 hrs (Harrigan and McCance, 1976). Organoleptic quality evaluation of blended guava and guava fruit leather was done by a panel of semi-skilled judges (6) by adopting a hedonic rating system having 100 points with various sub-scores as colour (30), texture (30) and flavor (40). The experiment was laid out in completely randomized design (Cochran and Cox 1967) comprising of 4 replications. The mean values were evaluated by critical difference (CD) test at $5 \%$ level of significance by using ANOVA.

\section{Results and Discussion}

Various physico-chemical characteristic of fresh guava pulp ('Allabad Safeda') used for making leathers are presented in Table 1 . The pulp recovery, lye peeling loss and waste were observed as $48.71 \%, 8.54 \%$ and $42.71 \%$ respectively. Guava pulp had high moisture (89.35\%), TSS $8.73 \%$, acidity $0.44 \%$, ascorbic acid content (225.2 $\mathrm{mg} / 100 \mathrm{~g})$, reducing sugar $4.20 \%$, non-reducing sugars $1.79 \%$ and total sugars $5.99 \%$. Jain et al., $(2011)^{[10]}$ reported guava pulp recovery $54.8 \%$, TSS $13.63 \%$, acidity $0.47 \%$, pH 3.63 and ascorbic acid $204 \mathrm{mg} / 100 \mathrm{~g}$. The variations in nutritional contents might be due to different maturity/ripening stage and different agro-climatic region of growing area. These results were in agreement with findings in guava varieties by Dinesh and Vasugi (2010).

The yield data and drying ratio of prepared guava leather are presented in Table 2. During dehydration, there was decrease in the quantity of the final pulp due to concentration, it also concentrated various physico-chemical constituents of guava pulp. The yield and drying ratio of prepared leather was found to be $29.18 \%$ and $3.56 \%$ respectively. The moisture content of guava leather was initially $14.36 \%$, which significantly decreases during storage of 4 months. However, the decrease was more in punnet packing $(11.84 \%)$ and less in BOPP packaging (12.81 \%) which indicated that BOPP packaging was comparatively better barrier to moisture than punnet packaging. The decrease in moisture content may be due to evaporation of water from the leather (Mir and Nath, 1983). Naikare et al., (1998) reported that 16\% moisture level in fruit leather had extended shelf life and retained sensory and physical quality upto six months. Similar results of moisture content were reported in jackfruit bar by Okilya et al., (2010) and in guava bar Khan et al., (2014).

Total solids and titratable acidity of guava leather in both packaging materials exhibited a gradual increase during the storage period.The sample stored in punnet had higher increase in both total solid and titrable acidity due to higher loss of moisture compared to BOPP packed storage. The increase in acidity might also be due to rise in the concentration of weakly ionized acids and their salts during storage. Increase in acidity might also be due to formation of acids by degradation of polysaccharides and oxidation of reducing sugars or by breakdown of pectic substances and uronic acid (Hussain et al., 2008).

Data on ascorbic acid content of guava leather samples stored in both packaging materials showed that there was a gradual and considerable decline in ascorbic acid throughout the storage period (Table 3). Initial ascorbic acid content of $221.4 \mathrm{mg} / 100 \mathrm{~g}$ decreases significantly during storage of 4 months in both type of packaging. There was 127.3 and $138.5 \mathrm{mg} / 100 \mathrm{~g}$ retention of ascorbic acid in punnet and BOPP packed guava leather after 4 months of storage respectively. 
Table.1 Physico chemical characteristics of guava fruit ('Allahabad Safeda') pulp used for making guava leather

\begin{tabular}{|c|c|c|}
\hline Sl. No. & Parameters & values \\
\hline 1. & Pulp recovery (\%) & 48.71 \\
\hline 2. & Lye peeling loss (\%) & 8.54 \\
\hline 3. & Waste $(\%)$ & 42.71 \\
\hline 4. & Moisture (\%) & 89.35 \\
\hline 5. & Total Solids (TS) (\%) & 10.65 \\
\hline 6. & Acidity (\% citric acid) & 0.44 \\
\hline 7. & Total Soluble Solids ( ${ }^{0}$ Brix $)$ & 8.73 \\
\hline 8. & Ascorbic acid (mg/100g) & 225.2 \\
\hline 9. & Reducing Sugars (\%) & 4.20 \\
\hline 10. & Non-reducing Sugars (\%) & 1.79 \\
\hline 11. & Total Sugars $(\%)$ & 5.99 \\
\hline
\end{tabular}

Table.2 Yield and drying ration of guava fruit leather

\begin{tabular}{|ll|c|}
\hline 1. & Yield (\%) & $\mathbf{2 9 . 1 8}$ \\
\hline 2. & Drying ratio & 3.56 \\
\hline
\end{tabular}

Table.3 Physico-chemical characteristics of guava fruit leather during storage

\begin{tabular}{|c|c|c|c|c|c|c|c|}
\hline \multirow[t]{2}{*}{ Parameter } & \multirow[t]{2}{*}{ Initial } & \multicolumn{2}{|c|}{2 months } & \multicolumn{2}{|c|}{4 months } & \multirow[t]{2}{*}{ Sem \pm} & \multirow[t]{2}{*}{ CD } \\
\hline & & Punnets & BOPP & Punnet & BOPP & & \\
\hline Moisture (\%) & 15.04 & 12.84 & 13.86 & 11.85 & 12.66 & 0.63 & 1.60 \\
\hline Total solids (\%) & 85.25 & 87.16 & 86.14 & 88.15 & 87.20 & 0.81 & 2.04 \\
\hline Acidity (\%) & 1.40 & 1.51 & 1.45 & 1.52 & 1.49 & 0.05 & 0.19 \\
\hline Ascorbic acid (mg/100g) & 221.4 & 165.2 & 170.5 & 127.3 & 138.5 & 2.5 & 6.5 \\
\hline Reducing sugar (\%) & 45.12 & 48.09 & 46.99 & 49.86 & 48.03 & 2.71 & 9.16 \\
\hline Non-red sugar (\%) & 22.6 & 18.15 & 19.42 & 16.03 & 15.13 & 0.42 & 1.83 \\
\hline Total sugar (\%) & 67.74 & 66.24 & 66.41 & 65.89 & 63.16 & 0.82 & 2.12 \\
\hline NEB (OD at $420 \mathrm{~nm}$ ) & 0.139 & 0.268 & 0.247 & 0.387 & 0.328 & 0.340 & NS \\
\hline Water activity $\left(\mathbf{a}_{w}\right)$ & 0.59 & 0.58 & 0.59 & 0.57 & 0.57 & 0.01 & 0.04 \\
\hline
\end{tabular}

Table.4 Organoleptic score of guava fruit leather during storage

\begin{tabular}{|c|c|c|c|c|c|c|c|}
\hline \multirow[t]{2}{*}{ Parameter } & \multirow[t]{2}{*}{ Initial } & \multicolumn{2}{|c|}{2 months } & \multicolumn{2}{|c|}{4 months } & \multirow[t]{2}{*}{ Sem \pm} & \multirow[t]{2}{*}{ CD } \\
\hline & & Punnets & BOPP & Punnet & BOPP & & \\
\hline Colour (30) & 24.86 & 20.49 & 24.86 & 18.27 & 19.26 & 0.69 & 2.41 \\
\hline Texture (30) & 23.46 & 20.99 & 21.67 & 18.26 & 19.48 & 0.42 & 2.01 \\
\hline Flavour (40) & 31.14 & 25.67 & 26.24 & 23.25 & 24.89 & 0.72 & 2.62 \\
\hline Overall acceptability (100) & 79.46 & 66.73 & 66.73 & 59.78 & 63.63 & 1.39 & 4.63 \\
\hline
\end{tabular}


Table.5 Microbial load of guava fruit leather at 4 months of storage

\begin{tabular}{|c|c|c|}
\hline \multirow{2}{*}{ Parameter } & \multicolumn{2}{|c|}{ 4 months } \\
\cline { 2 - 3 } & Punnet & BOPP \\
\hline Total viable count $(\mathbf{c f u} / \mathbf{m l})$ & $2 \times 10^{1}$ & Nil \\
\hline Yeast $(\mathbf{c f u} / \mathbf{m l})$ & Nil & Nil \\
\hline Mould $(\mathbf{c f u} / \mathbf{m l})$ & Nil & Nil \\
\hline Lactic acid bacteria(cfu/ml) & Nil & Nil \\
\hline Coliform bacteria(cfu/ml) & Nil & Nil \\
\hline
\end{tabular}

Storage of guava leather at ambient temperature $\left(25 \pm 5^{0} \mathrm{C}\right)$ indicated that BOPP packaging was comparatively better barrier to ascorbic acid degradation than punnets packaging. The decrease in ascorbic acid might be due to catalytic activity of fructose, thermal degradation and subsequent oxidation due to light. The losses of ascorbic acid is probably attributable to oxidation of ascorbic acid to dehydroascorbic acid followed by hydrolysis to 2,3-diketogluconic acid, which then undergoes polymerization to other nutritionally inactive products (Dewanto et al., 2002). Similar results have been reported by Ruiz et al., (2012) in applebar during storage.

There was a gradual increase in reducing sugar while non-reducing sugar decreases during 4 months of storage in both type of packaging of guava leather. It might be due to the inversion of non - reducing sugars into reducing sugars and the conversion of polysaccharides to monosaccharides (Sharma et al., 2012). Total sugar content slightly increased during storage which can be attributed to loss of moisture during storage leading to concentration. Similar results have been recorded in sapota -guava bar during 3 months of storage period (Sreemathi et al., 2008) and in apricot - soy toffees (Thakur et al., 2007).

There was a drastic increase in non-enzymatic browning (OD at $420 \mathrm{~nm}$ ) of leather at initial (0.139) during 4 months of storage in punnets
(0.387) and BOPP (0.328) packaging. The increase in non-enzymatic browning during storage might be due to loss of sulphur dioxide, conversion of ascorbic acid to furfural compounds and inversion of sugar (Vijayanand et al., 2000). However, BOPP stored guava leather were more effective in reducing non-enzymatic browning due to higher gas and moisture barrier properties.

There was a non-significant difference in water activity of guava leather during storage and it ranged from 0.59 to 0.57 . Fruit products with moisture content of $13-25 \%$ have water activity less than 0.8 , below which most of the microbial growth especially bacteria, is impeded (Jay et al., 2005). The level of water activity (0.55) was good enough for low rates of non-enzymatic browning and enzymatic activity as reported by Natalia et al., (2012). Demarchi et al., (2013) reported water activity $\left(a_{\mathrm{w}}\right)$ of 0.699 in apple leather.

The sensory score of guava leather during 4 months of storage is given in table 4. Initially, it had colour score of 24.86 (out of 30), texture score of 23.46 (out of 30), flavour score of 31.14 (out of 40) and overall acceptability of 79.46 (out of 100). During storage organoleptic acceptability of guava leather significantly decreased in both types of packaging but was still acceptable to the panellist. Organic acid and sugars ratio primarily creates a sense of taste which is perceived by specialized taste buds on the tongue. Decrease in taste score during storage 
might be due to due to fluctuations in acids, $\mathrm{pH}$ and sugar/acid ratio. Decline in guava leather colour score might be due to change in colour attributed to Maillard and enzymatic browning, ascorbic acid degradation and polymerization of anthocyanins with other phenolics (Garcia et al., 1999; Khan et al., 2015). Changes in flavour are the most sensitive index to quality deterioration during storage followed by colour (Barrett et al., 2010). However, samples stored in BOPP packaging (overall acceptability of 63.63) recorded higher acceptability compared to punnet packaging (overall acceptability of 59.78). The result indicated that guava leather could be acceptable upto 4 months of storage under ambient condition; thereafter it was unacceptable for consumption.

The microbial load in guava fruit leather at the end of storage is presented in Table 5. Total viable count was observed in case of punnet packaging after 4 month of storage while there was no growth in BOPP packaging. In both type of packaging, there was no growth of yeast, mould, lactic acid bacteria and coliform bacteria at the end of storage. This might be due to low water activity and action of preservatives. Total viable count of all guava leather samples was well within permissible limits of FSSAI, 2010. As per FSSAI (2010) guideline, the yeast and mould should be less than 100 count/gm. Similar finding was reported by Kadam et al., (2012) while evaluating the quality of guava products. Thus, guava leather was stable and microbiologically safe for consumption.

Based on physico-chemical, sensory acceptability and microbial analysis, guava leather could be stored upto 4 months in ambient condition. Significant differences were observed in various characteristic of guava leather during storage. The physicochemical changes during storage were more pronounced in samples packed in punnets packaging than BOPP packaging. In case of microbiological analysis, no detectable yeast and mold and negligible total viable count were observed in all packed leather samples during 4 months of storage period, thus the guava leather samples were regarded safe for consumption. On the basis of sensory evaluation, BOPP packed guava leather was ranked better and proved to be more suitable for storage. For effective reduction in various deteriorative changes, BOPP packaging may be effectively utilized to minimize these changes compared to punnet storage.

\section{References}

A.O.A.C. 2001. Official Methods of Analysis of the Association of Official Analytical Chemists, II Edn., Washington DC.

Andress, E.L., Harrison, J.A., Reynolds, S. and Williams, P. 2006. So easy to preserve. Cooperative Extension/The University of Georgia, College of Family and Consumer Sciences, College of Agricultural and Environmental Sciences.

Archana, A., and Siddiqui, S. 2004. Biochemical changes in guava fruits under various modified conditions. Haryana J. Hort. Sci.; 33: 209-12.

Barrett, D.M., Beaulieu, J.C. and Shewfelt, R. 2010. Color, flavor, texture, and nutritional quality of fresh-cut fruits and vegetables: desirable levels, instrumental and sensory measurement, and the effects of processing. Cri. Rev. Food Sci. Nutri. 50(5): 369-89.

Bose, T.K., Mitra, S.K., Farooqui, A.A. and Sandhu, M.K. 1999. Tropical Horticulture. 1st ed. NayaProkash Publication, Kolkata, 297.

Cochran, W.G. and Cox, G.M. 1964. Experimental Designs. Wiley, New York. 
Demarchi, S.M., Ruiz, N.A., Concellón, A. and Giner, S.A. 2013. Effect of temperature on hot-air drying rate and on retention of antioxidant capacity in apple leathers. Food Bioproducts Process. 91(4): 310-8.

Dewanto, V., Wu, X., Adom, K.K. and Liu, R.H. 2002. Thermal processing enhances the nutritional value of tomatoes by increasing total antioxidant activity. J. Agric. Food Chem. 50(10): 3010-4.

Dinesh, M.R. and Vasugi, C. 2010. Guava improvement in India and future needs. J. Hort. Sci. 5(2): 94-108.

FSSAI. 2010. Food Safety and Standards Regulations, Ministry of Health and Family Welfare, New Delhi, 312.

García, V.C., Zafrilla, P., Romero, F., Abellán, P., Artés, F. and Tomás- Barberán, F.A. 1999. Color stability of strawberry jam as affected by cultivar and storage temperature. $\mathrm{J}$. Food Sci. 64(2): 243-7.

Harrigan, W.F. and McCance, M.E. 1976. Laboratory methods in food and dairy microbiology. Academic Press Inc. (London) Ltd.

Hussain, I., Zeb, A., Shakir, I. and Shah, A.S. 2008. Combined effect of potassium sorbate and sodium benzoate on individual and blended juices of apricot and apple fruits grown in Azad Jammu and Kashmir. Pak. J. Nutr. 7(1): 181-5.

Jain, P.K., Jain, P. and Nema, P.K. 2011. Quality of guava and papaya fruit pulp as influenced by blending ratio and storage period. Am. J. Food Technol. 6(6): 507-12.

Jay, M.J., Loessner, M.J. and Golden, D.A. 2005. Modern Food Microbiology. 7th ed. Springer Science, USA.

Kadam, D.M., Kaushik, P. and Kumar, R. 2012. Evaluation of guava products quality. Int. J. Food Sci. Nutri. Eng. 2(1): 7-11.
Kanwal, N., Randhawa, M.A. and Iqbal Z. 2016. A review of production, losses and processing technologies of guava. Asian J. Agri. Food Sci. 4(02): 96-101.

Khan, M., Ayub, M., Durrani, Y., Wahab, S., Ali, M., Ali, S.A., Shakoor, A. and Rehman, Z. 2014. Effect of sucrose and stabilizer on the overall quality of guava bar. World J. Pharma. Sci. 3(5): 130-46.

Khan, S.H., Khan, A., Litaf, U., Shah, A.S., Khan, M.A., Ali, M.U., Shah, F.N., Maqbool, Z., Adnan, M. and Rani, S. 2015. Effect of different concentration of guava pulp, apple pulp and sugar solution on the shelf stability of blend leather storage at ambient temperature. J. Food Process Technol. 6: 466 doi:10.4172/2157-7110.1000466

Leite, K.M., Tadiotti, A.C., Baldochi, D. and Oliveira, O.M. 2006. Partial purification, heat stability and kinetic characterization of the pectin methylesterase from Brazilian guava, Paluma cultivars. Food Chem. 94(4): 565-72.

Mir, M.A. and Nath, N. 1993. Storage changes in fortified mango bars. J. Food Sci. Technol. 30(4): 279-82.

Naikare, S.M., Jadhaw, M.S. and Gawade, B.J. 1998. Processing of fruit leather and evaluation of its quality during storage. Poster abstract. IFCON C-5.22.

Natalia, A., Quintero, R.A., Silvana, M.B., Demarchi, A., Facundo, J., Massolo, A., Luis, M., Rodoni, A. and Sergio, A.G. 2012. Evaluation of quality during storage of apple leather. LWT - Food Sci. Technol. 47: 485-492.

Okilya, S., Mukisa, I.M. and Kaaya, A.N. 2010. Effect of solar drying on the quality and acceptability of jackfruit leather. Electronic J. Env. Agric. Food Chem. 9(1): 101-111.

Ruiz, N.A., Demarchi, S.M., Massolo, J.F., Rodoni, L.M. and Giner, S.A. 2012 Evaluation of quality during storage of 
apple leather. LWT-Food Sci. Technol. 47(2): 485-92.

Sharma, S.K., Chaudhary, S.P., Rao, V.K., Yadav, V.K. and Bisht, T.S. 2013. Standardization of technology for preparation and storage of wild apricot fruit bar. J. Food Sci. Technol. 50(4): 784-90.

Sreemathi, M., Sankaranarayanan, R. and Balasubramanyan, S. 2008. Sapotapapaya bar. Madras Agric. J. 95(1/6): 170-3.
Thakur, N., Thakur, N.S., Suman, M., Kaushal, B.B. and Sharma, S. 2007. Apricot soya toffees-a protein enriched product. Indian Food Pack. 61(4):77.

Vijayanand, P., Yadav, A.R., Balasubramanyam, N. and Narasimham, P. 2000. Storage stability of guava fruit bar prepared using a new process. LWT-Food Sci. Technol. 33(2): 132-7. Yadav, I.S. 1997. Search for quality cultivars. The Hindu, Survey of Indian Agriculture. New Delhi, 132.

\section{How to cite this article:}

Jeebit Singh, L., R.B. Tiwari and Ranjtiha, K. 2019. Storage Stability of Guava Leather in Two Type of Packaging. Int.J.Curr.Microbiol.App.Sci. 8(07): 2465-2472.

doi: https://doi.org/10.20546/ijcmas.2019.807.303 